SELENIUM CONCENTRATIONS IN WATERS TRIBUTARY TO AND

IN THE VICINITY OF THE RESTERSON NATIONAL WILDLIFE REFUGE, FRESNO AND MERCED COUNTIES, CALIFORNIA

By T. S. Presser and I van Barnes

U.S. GEOLOGICAL SURVEY

Water Resources Investigations Report 84-4122

Menlo Park, Callfornia May 1984

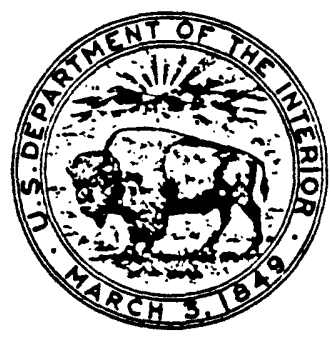


UNITED STATES OF THE INTERIOR

WILLIAM P. CLARK, Secretary

GEOLOGICAL SURVEY

Dallas L. Peck, Director

For additional information write to:

T. S. Presser

U.S. Geological Survey

Water Resources Division

$\mathrm{Ma}$ ils top 434

Menlo Park, CA 94025
Copies of this report can be purchased from:

Open-File Services Section Western Distribution Branch U.S. Geological Survey Box 25425, Federal Center Denver, CO 80225

Telephone: (303) 234-5888 


\section{ILLUSTRATIONS}

Figure 1. Sampling site locations in the vicinity of Kesterson National Wildlife Refuge..............

Figure 2. Sampling site locations of inflows into the San Luis Drain............................ 5

Figure 3. Map of the Kesterson National Wildlife Refuge....... 6

Figure 4. Analytical method for selenium in water............

\section{TABLES}

Table 1. Loctions of sampling sites..................... 8

Table 2. Results of analysis for $\mathrm{Se}, \mathrm{Na}, \mathrm{SO}_{4} \delta \mathrm{D}$ and $\delta{ }^{18} \mathrm{O} \ldots \ldots .17$

Table 3. Comparison of results of analyses for Se............ 20 
SELENIUM CONCENTRATIONS IN WATERS TRIBUTARY TO

AND IN THE VICINITY OF THE KESTERSON NATIONAL WILDLIFE REFUGE, FRESNO AND MERCED COUNTIES, CALIFORNIA

By T. S. Presser and Ivan Barnes

ABSTRACT

Analyses were made for selenium in waters and other materials of the Kesterson National Wildiife Refuge. Analyses were also made of source agricultural dralnage waters from the San Luis Drain discharged into the refuge, and surrounding irrigation supply and return waters.

Selenium concentrations range from 140 to 1,400 micrograms per liter $(\mu g / L)$ in irrigation drain waters supplied to the San Luis Drain. The selenium supplied to the Kesterson National Wildilfe Refuge is to a small extent precipltated in sodium sulfate (thenardite) but a higher concentration was found in an algal mat.

Most other waters of the area contain less than detectable $(<2 \mu g / L)$ concentrations of selenium.

Oxidation of organic matter and reduction of selenate $\left(\mathrm{SeO}_{4}^{-2}\right)$ to selenite $\left(\mathrm{SeO}_{3}^{-2}\right)$ were found to be necessary for a quantitative analysis of total selenium. 


\section{INTRODUCT ION}

The United States Fish and Wildlife Service (U.S.F. \& W.S.) reported to the U.S. Geological Survey (U.S.G.S.) that unusually high rates of mutation occurred in hatchlings of wild waterfowl (up to $40 \%$ for coots) in the Kesterson National Wildlife Refuge (Felix Smith, oral commen, July, 7 1983). The U.S.F. \& W.S. further stated that analyses of hatchling tissue showed high selenium (Se) concentrations. Information on Se concentrations in fish from the Kesterson Reservoir and San Luis Drain was released later in a report by the U.S. Bureau of Reclamation (February, 1984). Concentrations of Se were as much as 100 times higher than those of fish from the Volta Wildlife Refuge comparison test area.

A map of California (No. 214-308-5165), Central Valley Project, San Luis Unit, West San Joaquin Division by the Bureau of Reclamation in September, 1975 gives a description of the San Luis Drain Federal Facllity:

"(San Luis Drain) will be a concrete-lined canal extending 188 miles from the vicinity of Kettleman City to the lower San Joaquin-Sacramento Delta. The Drain will convey and dispose of subsurface irrigation return flows from the San Luis Service area. A feature of the Drain is the Kesterson Reservoir area where water is stored and regulated. The reservoir is designated as a National Wildlife Refuge for the conservation and management of wildlife and recreation."

Predictions about the mobllity of Se are given by Lakin in a chapter in "Selenium in Agriculture" (1961). He stated that in regions of low rainfall and alkaline soils, part of the se would occur as selenate $\left(\mathrm{SeO}_{4}^{-2}\right)$. As $\mathrm{SeO}_{4}^{-2}$, it would be available to vegetation and readily transported in ground water. In contrast, are regions of acid environment where se would tend to occur in ferric hydroxide precipitates as basic ferric selenite 
$\left(\mathrm{Fe}_{2}(\mathrm{OH})_{4} \mathrm{SeO}_{3}\right)$. This form is more stationary and presumably of low avallability to plants. The areas supplying water to the San Luls Draln have low rainfall, approximately 10 inches annually, (National Oceanic and Atmospheric Administration, 1981).

Because of the potential hazards of mutagens in water, the U.S.G.S. Initiated a study of the waters in and tributary to the Kesterson National Wildife Refuge. Other water supplies in the area were studied to provide a basis for comparison with the Kesterson water supply. The study included but was not limited to analyses for Se.

The chemistry of Se is complex, especially in natural systems where a range of oxidation states may be expected and a varlety of blochemical effects may be anticipated. Further complications were expected in analytical procedures because large variations in concentrations of solutes lead to complex matrix effects. A broad analytical experlence with wide ranges of inorganic solutes in water facliltated this study (Presser and Barnes, 1974). FIELD AND HYDROLOGIC RELATIONS

Maps of the study area are shown in Figures 1 and 2. Approximately 80 miles of the San Luls Drain are now completed, from Burrel, 20 miles southwest of Fresno in the south to Kesterson in the north. Figure 1 shows sample locations in the vicinity of the Kesterson National Wildlife Refuge. Figure 2 shows sample locations of inflows into the San Luis Drain. The two areas are not contiguous. Figure 3 is a map of Kesterson National Wildife Refuge distributed by the State of California, Department of Fish and Game. The evaporation ponds are numbered 1 through 12. The San Luis Drain borders the ponds on the east. The only visible entries from the San Luis Drain into the Kesterson ponds are into ponds 2 and 12 . The water evaporates as 1 f flows from pond to pond in a northerly direction from pond 2 to pond 11 where flow 


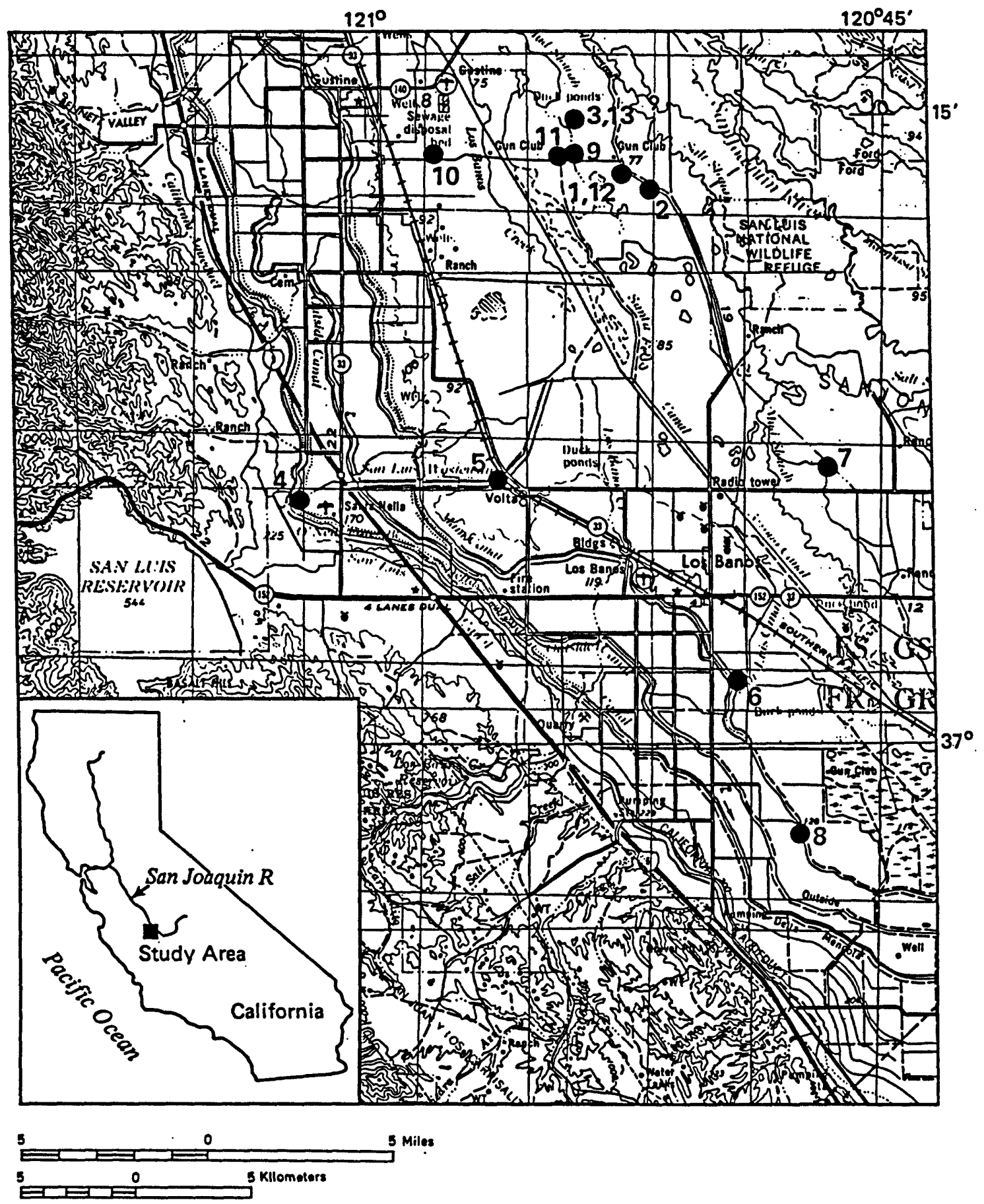

FIgure I.--Sampling site locations in the vicinity of Kesterson National Wildlife Refuge. 


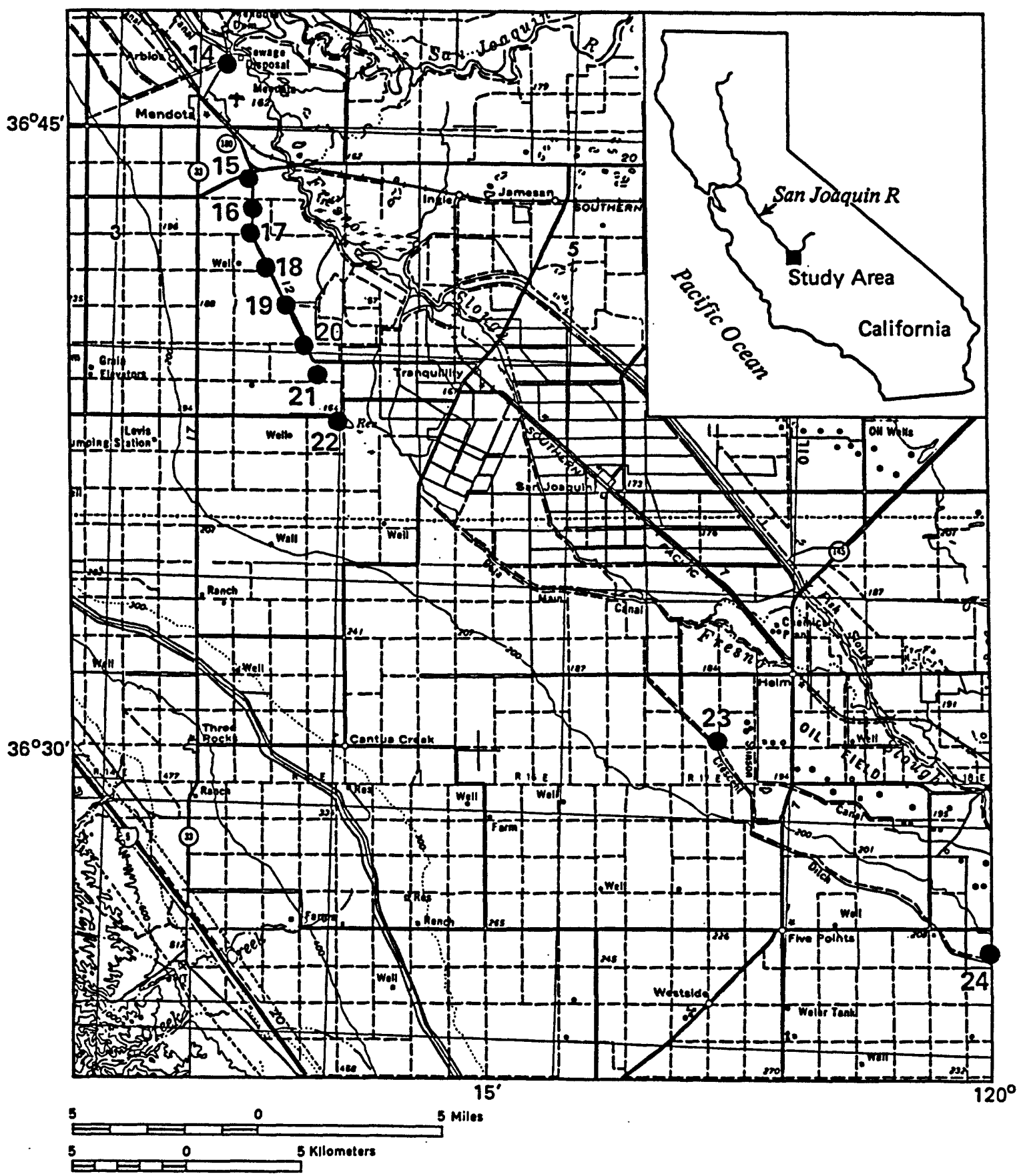

Figure 2.--Sampling site locations of inflows into the San Luis Drain. 


\section{KESTERSON NATIONAL WILDLIFE REFUGE}

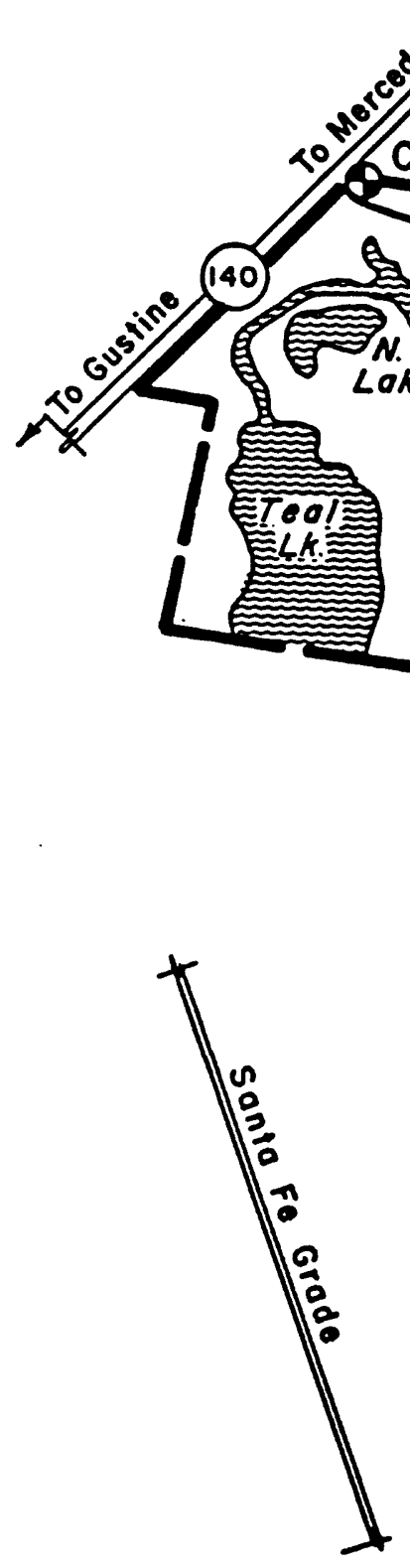

LEGEND

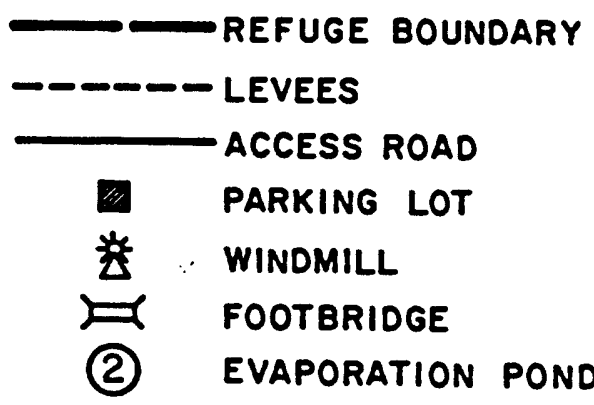

\section{MERCED COUNTY}

CHECK STATION

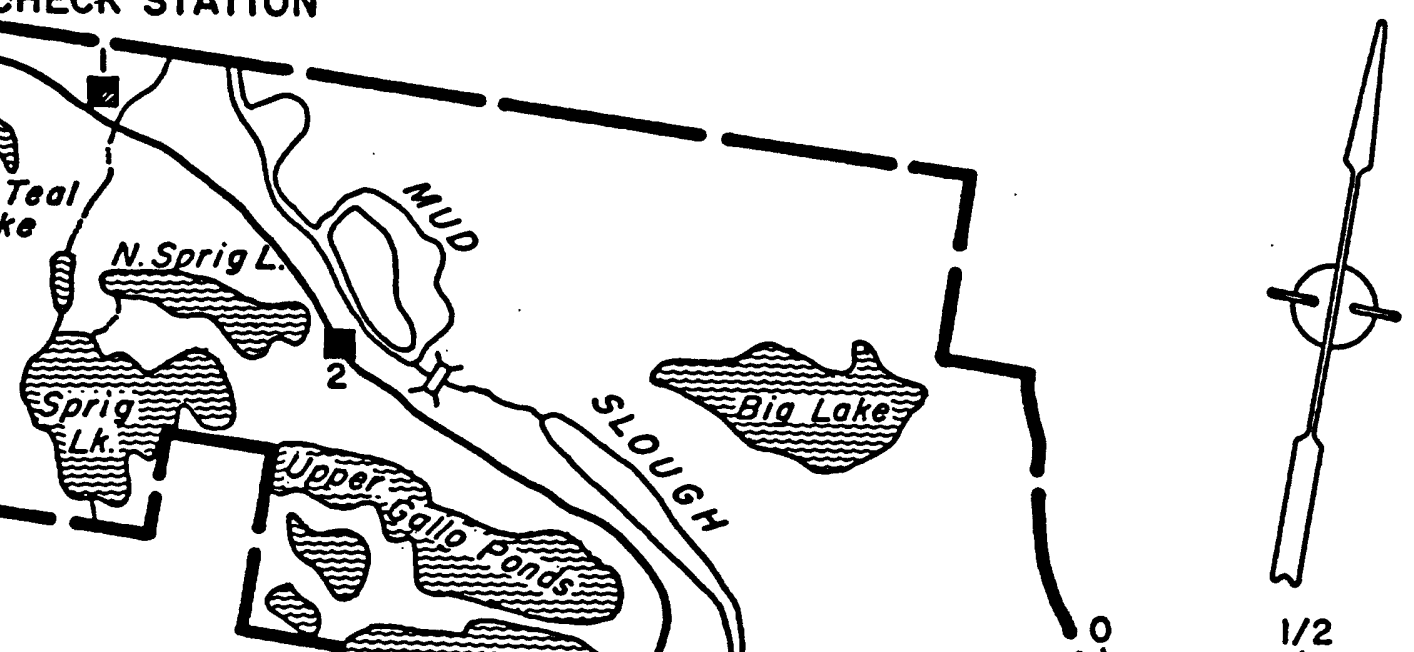


normally terminates. Pond 12 receives flow intermittantly when there is a surplus of water in the San Luis Drain.

Samples were collected in August, 1983 to show conditions characteristic of the study area at the end of the dry sumer. Water samples were obtained from the Kesterson Ponds 2 and 11. A salt crust and an underiying algal mat were also sampled at pond 11.

Samples were collected in October, 1983 of irrigation suppiy waters and irrigation return waters in the surrounding area. These included the DeltaMendota Canal, the Volta Drain, and the San Luis Canal (Main Canal water).

In late November and early December, samples of the ten actively inflowing waters to the San Luis Drain were collected. Stagnant water in entries to the drain were not collected. The waters of the south end of the San Luis Drain, Kesterson Pond 11 and the inflow into pond 2 were also obtained.

Sample numbers, locations, descriptions and dates are given in Table 1. FIELD METHODS

Water samples for subsequent selenium and other determinations were collected in stainless steel pressure vessels. The vessels were rinsed three times with distilled water after each use and were rinsed three times with the next water to be sampled before the sample was collected.

Samples were pressure filtered in the field through membrane filter discs $142 \mathrm{~mm}$ in diameter. The large diameter allowed faster filtration of samples that were turbid with algae and sediment. The effective pore size of the filters is 0.1 micrometers. Pressure was supplied by compressed nitrogen. After use the stainless steel filter holder was rinsed three times with distilled water. The first filtrate of the next sample was discarded and subsequent filtrate was used to rinse sample bottles and caps three times 
Table 1.-Locatlons of sompling sites.

\begin{tabular}{|c|c|c|c|c|}
\hline Map & Number & Name & Location & Date \\
\hline 1 & $00681 \mathrm{B83}$ & $\begin{array}{l}\text { Kosterson Pond 2, seuth side, } \\
20 \text { ft off shore }\end{array}$ & $\begin{array}{l}\text { sec. } 21 \\
\text { T. } 8 \text { S., R } 10 \mathrm{E} .\end{array}$ & 3 Ams. 83 \\
\hline 2 & Co69 IB83 & $\begin{array}{l}\text { San Luls Draln at brldse, } 0.6 \\
\mathrm{mi} \mathrm{NW} \text { of Lander Ave., at sec. } \\
22 \text { and } 27 \text { boundery }\end{array}$ & $\begin{array}{l}\text { SW, sec. 22, } \\
\text { T. S., R. } 10 \text { E. }\end{array}$ & 3 Aus. 83 \\
\hline 3 & $\infty 701883$ & $\begin{array}{l}\text { Kesterson Pond } 11 \text {, south } 1 \text { do } \\
\text { of Intersectlon of roads } \\
\text { rounding pond } 11 \text { and that } \\
\text { between ponds } 9 \text { and } 19\end{array}$ & $\begin{array}{l}\text { SW, sec. B, } \\
\text { T. S., R. } 10 \mathrm{E} \text {. }\end{array}$ & 3 Ans. 83 \\
\hline 4 & Q110TP83 & $\begin{array}{l}\text { Delia-mendota Canal at sate to } \\
\text { San Luls Wastoway }\end{array}$ & $\begin{array}{l}\text { SE, sec. } 1, \\
T_{0} 10 \text { S., R. } 8 E .\end{array}$ & 12 Oct. 83 \\
\hline 5 & C111TP83 & $\begin{array}{l}\text { Volta drain at scrowgate, SE } \\
\text { side of and Immediately up- } \\
\text { stream of discharge Into San } \\
\text { Luls Wasteway }\end{array}$ & $\begin{array}{l}\text { Sw, sec. 36, } \\
\text { T. 9., R. } 9 \text { E. }\end{array}$ & 12 Oct. 83 \\
\hline 6 & C112TP83 & $\begin{array}{l}\text { Main Canal at discharge Into } \\
\text { San Luls Canal }\end{array}$ & $\begin{array}{l}\text { NE, sec. } 36, \\
\text { T. } 10 \text { S., R. } 10 \text { E. }\end{array}$ & 13 Ocs. 83 \\
\hline 7 & Q113TP83 & $\begin{array}{l}\text { Devon draln at pumplng station, } \\
0.6 \mathrm{ml} \text { north of Henry miller } \\
\text { Are. }\end{array}$ & $\begin{array}{l}\text { NW, sec. 33, } \\
\text { T. S., R. } 11 E .\end{array}$ & $130 c t .83$ \\
\hline 8 & $\infty 114$ TP83 & $\begin{array}{l}\text { Irrlgation return water at dis- } \\
\text { charge into disch paraliel to } \\
\text { to and Immediately west of } \\
\text { Maln Canal, south of farm } \\
\text { eccess road }\end{array}$ & $\begin{array}{l}\text { Nw, sec. 20, } \\
T .11 \text { S., R. } 11 \mathrm{E} .\end{array}$ & 14 Oet. 83 \\
\hline 9 & CQ115TP83 & $\begin{array}{l}\text { Fremont and Mud Sloughs at } \\
\text { confluence, north slde of Gun } \\
\text { Club Road }\end{array}$ & $\begin{array}{l}\text { Sw, sec. 17, } \\
\text { T. S S., R. } 10 \mathrm{E} .\end{array}$ & 14 Oet. 83 \\
\hline 10 & C116TP83 & $\begin{array}{l}\text { Water pumped Inte north flowing } \\
\text { ditch from south flowing ditch } \\
\text { north slde of Gun Club Road }\end{array}$ & $\begin{array}{l}\text { S, sec. 15, } \\
\text { T. S., R. } 9 \mathrm{E} \text {. }\end{array}$ & 14 Oet. 83 \\
\hline 11 & @118TP83 & $\begin{array}{l}\text { Santa Fo Canal, north slde of } \\
\text { of Gun Club Road }\end{array}$ & $\begin{array}{l}\text { SE, sec. 18, } \\
\text { T. } 8 \text { S., R. } 10 \text { E. }\end{array}$ & 30 Nor. 83 \\
\hline 12 & CQ119TP83 & $\begin{array}{l}\text { San Luls Draln Into Kesterson } \\
\text { Pond 2, south side of Gun } \\
\text { Club Road }\end{array}$ & $\begin{array}{l}\text { N, sec. } 21, \\
\text { T. } 8 \text { S., R. } 10 \mathrm{E}\end{array}$ & 30 Nov. 83 \\
\hline 13 & Q120TP83 & $\begin{array}{l}\text { Kesterson Pond 11, south ide, } \\
\text { same locetion as } 0 \text { joib83 }\end{array}$ & $\begin{array}{l}\text { SW, sec. 8, } \\
\text { T. } 8 \text { S., R. } 10 \mathrm{E} .\end{array}$ & 30 Nov. 83 \\
\hline 14 & Q121TP83 & $\begin{array}{l}\text { Waste entry Into San Luls Draln } \\
\text { at Bass Avenue, Mendota }\end{array}$ & $\begin{array}{l}\text { NE, sec. } 30, \text { is } \\
T, 13 \text { S., } R_{*} \text { is }\end{array}$ & 1 Dec. 83 \\
\hline 15 & @122TP83 & $\begin{array}{l}\text { Waste entry Into San Luls Draln } \\
\text { at Panoche Road }\end{array}$ & $\begin{array}{l}\text { Nw, sec. 8, } \\
\text { T. } 14 \text { S., R. } 15 \mathrm{E} .\end{array}$ & 1 Dec. 83 \\
\hline 16 & Q123TPB3 & $\begin{array}{l}\text { Waste entry Into San Luls Draln } \\
\text { at Callfornla Road }\end{array}$ & $\begin{array}{l}\text { Nw, sec. 17, } \\
\text { T. } 14 \text { S., R. } 15 \mathrm{E}\end{array}$ & 1 Dec. 83 \\
\hline 17 & Q124TP83 & $\begin{array}{l}\text { Waste entry Into San Luis Drain } \\
\text { at Jensen Avenue }\end{array}$ & $\begin{array}{l}\text { SW, sec. 17, } \\
\text { T. } 14 \text { S., R. } 15 \mathrm{E} .\end{array}$ & 2 Dec. 83 \\
\hline 18 & O125TP83 & $\begin{array}{l}\text { Waste entry Into San Luls Draln } \\
\text { at North Avenue }\end{array}$ & $\begin{array}{l}\text { SE, sec. 20, } \\
\text { T. } 14 \text { S., R. } 15 \mathrm{E} .\end{array}$ & 2 Dec. 83 \\
\hline 19 & Q126TP83 & $\begin{array}{l}\text { Waste entry Into San Luls Draln, } \\
\text { south of Mendota Wildilfe } \\
\text { Management Area Hoadquarters }\end{array}$ & $\begin{array}{l}\text { NW, sec. 33, } \\
\text { T. } 14 \text { S., R. is E. }\end{array}$ & 2 Dec. 83 \\
\hline 20 & Q127TP83 & $\begin{array}{l}\text { Wasto entry Into San Luls Drain } \\
\text { at Amerlcan Road }\end{array}$ & $\begin{array}{l}\text { NE, sec. 4, } \\
T .15 \text { S., R. is E. }\end{array}$ & 2 Dec. 83 \\
\hline 21 & Q128TP83 & $\begin{array}{l}\text { Waste ontry Into San Luls Drain } \\
\text { at Lincoln Avenue }\end{array}$ & $\begin{array}{l}\text { Sw, sec. 3, } \\
T .15 \text { S., R. } 15 \mathrm{E} .\end{array}$ & 2 Dec. 83 \\
\hline 22 & Q129TP83 & $\begin{array}{l}\text { Waste entry Into San Luls Draln } \\
\text { at Adams Avenue }\end{array}$ & $\begin{array}{l}\text { NE, sec. 15, } \\
T .15 S_{\bullet}, R_{\bullet} \text { is E. }\end{array}$ & 2 Dec. 83 \\
\hline 23 & @130тр83 & $\begin{array}{l}\text { Water entry through plpe cast } \\
\text { In east side of San Luls Drain } \\
\text { at Clarkson Avenue }\end{array}$ & $\begin{array}{l}\text { NE, sec. 32, } \\
T .16 \mathrm{~S}, \mathrm{R}, 17 \mathrm{E}\end{array}$ & 2 Dec. 83 \\
\hline 24 & Q131TP83 & $\begin{array}{l}\text { Standing water In south end of } \\
\text { San Luls Drain }\end{array}$ & 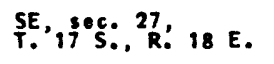 & 2 Dec. 83 \\
\hline
\end{tabular}


before filling with aliquots for the determinations.

Glass bottles with polyethylene inserts in the caps were used as containers for water samples for isotope anaiyses.

Conventional polyethylene bottles were used as containers for filtered samples for Se determination. One aliquot was acidified with nitric acid (Fa$\mathrm{HNO}_{3}$ ) and one with hydrochioric acid ( $\left.\mathrm{Fa}-\mathrm{HCl}\right)$, both to a pH less than 2.5 as measured with pH paper. Amounts of acids added to each sample were recorded. Shendrikar and West (1975) reported a loss of $2 \%$ when 1 miliigram per liter (mg/L) Se was preserved with $0.5 \%$ nitric acid $\left(H^{N O_{3}}\right)$ in polyethylene bottles for a test period of 15 days. The second set of samples was preserved with hydrochloric acid ( $\mathrm{HCl}$ ) because there are conflicting reports in the literature of different acids acting as an interferent in the hydride formation technique used for analyzing Se (Pierce and Brown, 1977). HCl was chosen because it is the acid used later in the hydride formation. Further information about the stability of Se in aqueous solutions is given in Cheam and Agemian (1980). Agreement in the literature exists that adjustment to a $\mathrm{pH}<2$ is adequate. Information on the preservation of the natural distribution of Se between its different oxidation states will be discussed later.

\section{LABORATORY METHODS}

\section{Waters}

Sodium was determined by atomic absorption spectrophotometry using a filtered, acidified ( $\left.F_{2}-H C l\right)$ sample. Deuterium and hydrogen (D/H) were released from water sampies for isotope analysis by reaction with uranium. The oxygen isotope ratio ${ }^{18} \mathrm{O} /{ }^{16} \mathrm{O}$, on water was measured on carbon dioxide in equilibrium with the water. Determinations were made of the $\mathrm{D} / \mathrm{H}$ and ${ }^{18} \mathrm{O} /{ }^{16} \mathrm{O}$ 
ratios using a Finnigan Mat $251^{1}$ gas source mass spectrometer. Sulfate was determined by ion chromatography on a filtered, unacidified sample. Estimates of organic carbon were made by determining total carbon and inorganic carbon and computing the difference and also by analyzing a sample which had been freed of inorganic carbon for total carbon. Samples were run on a Beckman Total Organic Carbon Analyzer Model 915-B.

Because prior knowledge of Se speclation was not avallable, precautions were taken to determine the total of whatever forms of Se were preserved in the sample aliquots, selenate $\left(\mathrm{SeO}_{4}^{-2}\right)$, selenite $\left(\mathrm{SeO}_{3}^{-2}\right)$ and/or elemental selenium $\left(S^{0}\right)$. Further differentiation had to be made as to whether the Se was combined with organic compounds since rather high organic carbon concentrations were suspected and found in the drain and ponds $(20$ to $60 \mathrm{mg} / \mathrm{L}$ C). Organic selenides $\left(\mathrm{Se}^{-2}\right)$ are volatile (Chan, 1975; Cutter, 1978 and 1982) and in general selenides were not preserved or looked for in these oxic waters. The analysis scheme is detailed in Figure 4.

In order to break down organo metal compounds the traditional oxidative digestion was applied to the waters as a first step in the determination of total Se. A digest applied specifically to se using acid and potassium persulfate $\left(\mathrm{K}_{2} \mathrm{~S}_{2} \mathrm{O}_{8}\right)$ is described by Goulden and Brooksbank (1974) as a manual step before introduction of the sample into an automated procedure. $\mathrm{K}_{2} \mathrm{~S}_{2} \mathrm{O}_{8}$ was also added as a further step in digestion for the analysis of mercury in organic mercurials, improving the recovery in waste waters to $100 \%$ (U.S. Environmental Protection Agency, 1971).

To twenty-five milliliters $(\mathrm{ml})$ of the acidified sample, $1 \mathrm{ml}$ of $5 \% \mathrm{wt} / \mathrm{v}$

1Use of brand names in this report is for identification purposes only and does not constitute endorsement by the U.S. Geological Survey. 

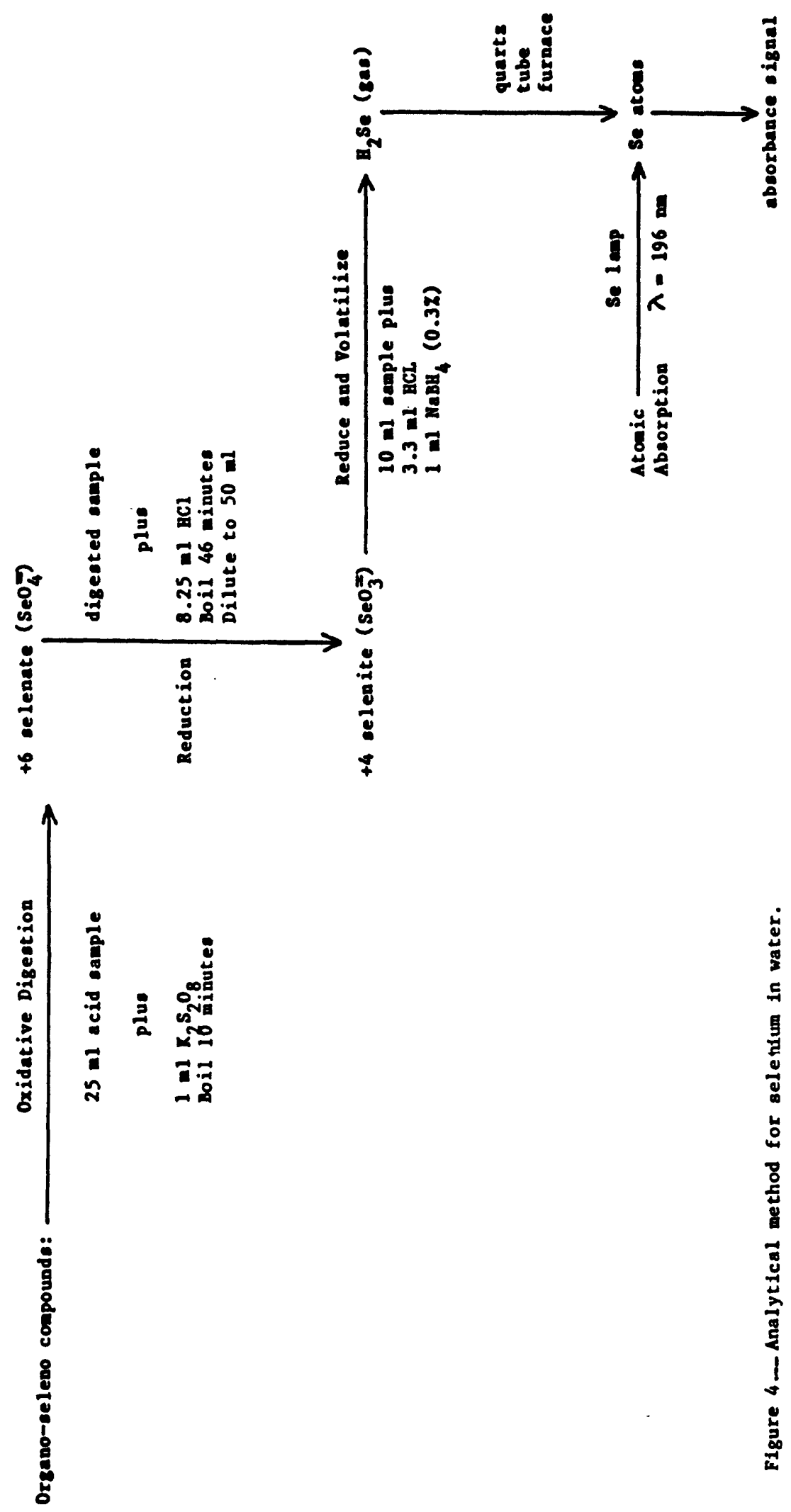

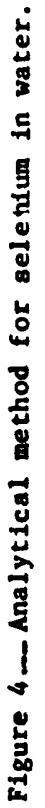


$\mathrm{K}_{2} \mathrm{~S}_{2} \mathrm{O}_{8}$ is added, the solution slowly heated to boiling and then boiled for 10 minutes. This acid step also, if solid material is present, either from precipitation after the sample was collected and filtered, e.g. Iron selenite, or In the case of the algal mat digests, desorbs or solubilizes the metal (U.S.G.S., 1979; Goulden and Brooksbank, 1974). Incomplete oxidation and volatllization both lead to erroneously low Se concentrations. Boiling longer than 10 minutes yields no increase in analyzed Se because of the decomposition of $\mathrm{K}_{2} \mathrm{~S}_{2} \mathrm{O}_{8}$ within that $t$ ime. No increase in Se recovery resulted from the addition of two times the amount of $\mathrm{K}_{2} \mathrm{~S}_{2} \mathrm{O}_{8}$ or two $t$ imes the amount of acid to the algal mat digests and pond 11 samples, those samples containing the most organics.

Analysis of a seienite standard by hydride generation after this first step showed no Se present indicating it was all oxidized to $\mathrm{SeO}_{4}^{-2}$. Selenite was chosen as a standard to check on any loss of selenite originally present in the samples and to check the completeness of $\mathrm{SeO}_{3}^{-2}$ to $\mathrm{SeO}_{4}^{-2}$ oxidation.

The inorganic seienium thus yielded by oxidation of organo selenium compounds, and the inorganic selenium originally present, now both as selenate $(+6)$, are reduced to selenite $(+4)$ before further reduction and analysis as selenium hydride (Cutter, 1978). As Cutter states in "Species Determination of Selenium in Natural Waters", the inorganic forms of Se $(+4$ and +6$)$ can be selectively reduced to hydride and analyzed spectrometrically. First, by his method for a total inorganic selenium concentration the sample was made $4 M$ in $\mathrm{HCl}$ and boiled vigorously for 4-5 minutes to reduce $\mathrm{SeO}_{4}^{-2}$ to $\mathrm{SeO}_{3}^{-2}$. The resultant solution was analyzed for Se by hydride generation. In a later publication (Cutter, 1983), boiling time was increased to between 12 and 30 minutes. "A selenite value is found by taking a second aliquot of sample, stripping the volatile selenides from the solution with hellum gas, and again 
anaiyzing the solution for se by hydride generation. The amount of $\mathrm{SeO}_{4}^{-2}$ is then calculated by difference: i.e. selenate = total Se - selenite. From the work of Cutter (1978) in which he presents a response curve of selenite and selenate to boliling in $4 \mathrm{M} \mathrm{HCl}$, an insight is given into the problem of not going far enough on the boiling curve to reduce all the selenate to selenite or of going too far and losing the seienite through piating out or aggiomerating of elemental selenium. As with the oxidation step, optimum reducing conditions were found to yield maximum quantities of selenium. Incomplete reduction to $\mathrm{SeO}_{3}^{-2}$ or reduction to elemental selenium ( $\left.\mathrm{Se}^{\circ}\right)$ both yield erroneously low amounts of selenium (Cutter, 1978 and Walker, 1976). Because the matrixes of these samples are not identical to those found by other workers, the optimization of reduction was conducted on actual samples from this study. In response to the many conditions imposed by Se chemistry, acid concentrations and length of time between and after the two pretreatment steps were always kept at a minimum.

The optimum reduction to $\mathrm{SeO}_{3}^{-2}$ was found to occur with the addition of $8.25 \mathrm{mi}$ of concentrated $\mathrm{HCl}$ and bolling for 46 minutes. From digested aliquots of the same sample (Table 3, CQ68IB83) the yield of selenium by analysis was: $155 \mu \mathrm{g} / \mathrm{L}$ Se ( 5 minutes boiling); $190 \mu \mathrm{g} / \mathrm{L}$ Se (17 minutes boiling); and $350 \mu \mathrm{g} / \mathrm{L}$ Se (46 minutes boiling). Boiling for 60 minutes yielded no further increase in Se by analysis, nor did increasing the acid concentration to 6 normal $(N)$. Determinations of Se in this water sample from Kesterson Pond 2 with no digestion and no reduction yielded $67 \mu \mathrm{g} / \mathrm{L} \mathrm{Se}$. A reduction of this water sample without the preliminary oxidation step showed a Se concentration of $300 \mu \mathrm{g} / \mathrm{L}$. With both steps included, the value was 350 $\mu g / L$ Se. Therefore, with no digestion and no reduction, $19 \%$ of the Se was recovered; with reduction only, $86 \%$ of the Se was recovered. 
A stronger reducing agent than $\mathrm{HCl}$ could have been used in the prereduction step. Substances that have been used include tin (Sn) (U.S.G.S., 1982) and aluminum (Al) (Goulden and Brooksbank, 1974). Problems occur with precipitation of elemental $\mathrm{Sn}$ or $\mathrm{Al}$ and the formation of $\mathrm{SnH}_{2}$ when $\mathrm{Se}$ is further reduced to the hydride unless the solution is kept above $90^{\circ} \mathrm{C}$. This is done as described by the above authors, using a block digestor and continuous, automated systems.

The last steps in the analysis are generation and measurement of selenium hydride $\left(\mathrm{H}_{2} \mathrm{Se}\right)$. A hydride generator coupled to an atomic absorption spectrophotometer was used. This method takes advantage of the property of Se to form a gas, $\mathrm{H}_{2} \mathrm{Se}$, in the -2 oxidation state. A review article of hydride generation techniques is given by Nakahara, (1983). An Instrumentation Laboratories Model 751 instrument equipped with a deuterium arc background corrector and an Atomic Vapor Accessory was used. The accessory is automated for one cycle per sample introduced. No secondary collection or stripping device was included.

Ten milliliters of the pre-digested and pre-reduced aqueous sample was pipetted into the generator and made $3 \mathrm{M}$ in $\mathrm{HCl}$. The system was put on automatic operation and purged with argon. The reducing agent, $0.3 \% \mathrm{NaBH}_{4}$, stabilized with $1 \% \mathrm{NaOH}$, is included in the closed system. It is pumped into the generator at a specified rate (\#2) and the sample is stirred with a magnetic stirrer. This $\mathrm{NaBH}_{4}$-acid reduction system has replaced the older metal-acid (e.g. $\left.\mathrm{Zn}-\mathrm{SnCl}_{2}-\mathrm{KI}\right)$ reduction system. Nakahara (1983) compares the two methods and lists among the advantages: applicability to other elements, yield increase, reaction time decrease, and blank-contamination reduction.

The selenide gas formed after a reaction time of 0.5 minute, (no argon flow) is swept into a quartz tube heated by an air-acetylene flame ( $\mathrm{T}>800^{\circ} \mathrm{C}$ ) 
using the stream of argon gas. The spike of selenide is decomposed to gaseous metal atoms and subsequent absorbance measurements are made at a wavelength of $196 \mathrm{~nm}$. Final molarity of $\mathrm{HCl}$ and $\mathrm{NaBH}_{4}$ used in the generator were initially determined from guidelines published by Instrumentation Laboratories. Final optimization for this particular system includes such variables as size of generation flask, amount of sample, purge rate, size of quartz tube, temperature of flame and integration time of signal. Further additions of $\mathrm{NaBH}_{4}$ yielded no further selenium. The working range for this method is 1 to $20 \mu \mathrm{g} / \mathrm{L}$ Se. Because of the type of water collected (agricultural drainage water) and the limit of $10 \mu \mathrm{g} / \mathrm{L}$ Se for drinking water (U.S. EPA, 1977), the sensitivity of this method was thought to be adequate.

Although one advantage of the gas generation method is removal of Se from ions present in aqueous solution, physical interferences may be present associated with the reduction or forming of the gas and the removal of the gas from the liquid (Cutter, 1978). These effects would vary with changes in acidity, salinity, oxidizing agents present (e.g. $\mathrm{HNO}_{3}$ ), pre-reductants used and other hydrides formed. An interference study for the hydride generation method was made by Pierce and Brown (1977). No significant interferences were reported from the inorganic elements normally found in waters. In further studies by the authors specifically associated with the pond and drain waters which were high in $\mathrm{SO}_{4}$ and $\mathrm{Na}$, no interference was found from $10,000 \mathrm{mg} / \mathrm{L} \mathrm{SO}_{4}$, $10,000 \mathrm{mg} / \mathrm{L} \mathrm{Na}, 10 \mu \mathrm{g} / \mathrm{L} \mathrm{As}, 10 \% \mathrm{HCl}, 10 \% \mathrm{HNO}_{3}$, and a digestion blank. Spectral interferences in the UV region were investigated by analyzing different dilutions of the pond and inflow waters. No aberrations were found: i.e. different dilutions yielded similar values.

Each sample was digested, reduced and analyzed on the same day. Differences in results of duplicate analyses of $\mathrm{Fa}-\mathrm{HCl}$ and $\mathrm{Fa}_{2}-\mathrm{HNO}_{3}$ samples 
ranged from $0 \%$ to $12 \%$ with an average of $6 \%$. For samples with the highest concentrations of Se, the second analysis included a dilution of the sample which decreased the Se to be digested to less than $500 \mu \mathrm{g} / \mathrm{L}$, the highest concentration of Se standard tested through the entire procedure. Recovery of Se added to pond samples averaged $98 \%$. Background samples of the various canals and secondary drains were digested, reduced and analyzed only once. These are distinguished by levels of Se $<10 \mu \mathrm{g} / \mathrm{L}$.

Solids

Minerals encountered in this study (thenardite and gypsum) were identified by both index of refraction measurements and x-ray diffraction using copper Ka radiation.

\section{RESULTS}

The results of the analyses of water samples for $\mathrm{Se}, \mathrm{Na}, \mathrm{SO}_{4}, \mathrm{D} / \mathrm{H}$ and ${ }^{18} \mathrm{O} /{ }^{16} \mathrm{O}$ are given in Table 2. It is apparently of little slgnificance whether aliquots are preserved with either $\mathrm{HCl}$ or $\mathrm{HNO}_{3}$. What is abundantly clear is that all the irrigation drainage water entering the San Luis Drain (Map Nos. 14 to 22) that was sampled, contained at least $140 \mu / \mathrm{L}$ Se and as much as 1,400 Mg/L. Fresh water entering the drain near its south terminus (Map No. 22) has less than $2 \mu \mathrm{g} / \mathrm{L}$ Se and serves to dilute the Se rich drain water. Water from the north end of the San Luis Drain at or near the discharge into Kesterson Pond 2 (Map Nos. 12 and 2) showed similar concentrations of Se despite different sampling times. A value of $330 \mu \mathrm{g} / \mathrm{L}$ Se was found in August during the dry season and $280 \mu \mathrm{g} / \mathrm{L}$ Se in December during the rainy season. The water of Pond 2 (Map No. 1) In August contained $350 \mu \mathrm{g} / \mathrm{L}$ Se. Note also, that the concentration of Se in pond 11 (Map Nos. 3 and 13) is much lower than that in pond 2 and that it increased from $14 \mu \mathrm{g} / \mathrm{L}$ in August to $60 \mu \mathrm{g} / \mathrm{L}$ in December. The results of analyses for Se in other irrigation supply and return 
Table 2.--Results of analyses for $\mathrm{Se}, \mathrm{N2}, \mathrm{SO}_{4}$ and $8 \mathrm{D}$ and $8^{18} \mathrm{O}$ [n.d. Indicates not determined.]

Map \# Number $\quad 4 \mathrm{~g} / \mathrm{L}$ Se $\left(\mathrm{F}_{2}-\mathrm{HCl}\right)$ $\mathrm{mg} / \mathrm{L} \mathrm{Na} \quad \mathrm{mg} / \mathrm{L} \mathrm{SO} \mathrm{SO}_{4}$ $\left(\mathrm{F}_{2}-\mathrm{HNO}_{3}\right)$
$8^{18} \mathrm{O}_{2} \mathrm{O}$ (per mi I SMOW)

\begin{tabular}{|c|c|c|c|c|c|c|c|}
\hline 1 & CQ681B83 & 330 & 350 & 2750 & 5550 & -4.24 & -46.6 \\
\hline 2 & CQ69iB83 & 320 & 330 & 2250 & 4700 & -5.42 & -52.1 \\
\hline 3 & CQ701883 & 14 & 15 & 6250 & 11500 & +4.03 & -7.0 \\
\hline 4 & CQ110TP83 & n.d. & $<2$ & 40 & 44 & -12.74 & -90.0 \\
\hline 5 & Q111TP83 & n.d. & $<2$ & 230 & 175 & -8.96 & -66.2 \\
\hline 6 & CQ112TP83 & n.d. & $<2$ & 49 & 90 & -13.67 & -97.9 \\
\hline 7 & CQ113TP83 & n.d. & $<2$ & 130 & 170 & $-12 \cdot 10$ & -90.4 \\
\hline 8 & CQ114TP83 & n.d. & 5 & 420 & 880 & -11.06 & -83.3 \\
\hline 9 & Q115TP83 & n.d. & $<2$ & 365 & 505 & -9.92 & -76.3 \\
\hline 10 & CQ116TP83 & n.d. & $<2$ & 86 & 165 & -12.03 & -89.9 \\
\hline 11 & CQ118TP 83 & n.d. & 10 & 210 & 360 & -6.22 & -50.8 \\
\hline 12 & CQ119TP83 & 280 & 280 & 2000 & 4100 & -6.55 & -56.4 \\
\hline 13 & C120TP83 & 62 & 60 & 3150 & 6000 & -2.01 & -13.4 \\
\hline 14 & CQ121TP83 & 195 & 200 & 1700 & 3050 & -7.92 & -60.7 \\
\hline 15 & Q122TP83 & 155 & 140 & 1500 & 3100 & -8.59 & -66.4 \\
\hline 16 & CQ1 23TP83 & 180 & 160 & 1450 & 3200 & -8.23 & $-64 \cdot 1$ \\
\hline 17 & C124TP83 & 190 & 180 & 935 & 2050 & -9.19 & -69.8 \\
\hline 18 & CQ1 25TP83 & 355 & 385 & 2300 & 4750 & -7.96 & -62.2 \\
\hline 19 & CQ1 26TP83 & 375 & 400 & 1650 & 3900 & -8.49 & -65.9 \\
\hline 20 & CQ127TP83 & 1350 & 1400 & 10500 & 22500 & -6.69 & $-60 \cdot 2$ \\
\hline 21. & Q1 28TP 83 & 500 & 490 & 2100 & 4350 & -8.57 & -68.9 \\
\hline 22 & CQ1 29TP83 & 1250 & 1400 & 8550 & 16500 & -7.40 & -61.8 \\
\hline 23 & @1 30TP83 & n.d. & $<2$ & 32 & 28 & -11.40 & -87.2 \\
\hline 24 & CQ131TP83 & n.d. & $<2$ & 30 & 48 & -2.15 & -37.9 \\
\hline
\end{tabular}


waters of the surrounding area (Map Nos. 4 through 11) which included the Volta area, show much lower Se concentrations ( $<2$ to $10 \mu g / L)$ than in the San Luis Drain and Kesterson Ponds 2 and 11.

A comparison of Se and sodium ( $\mathrm{Na}$ ) concentrations in water In Kesterson Ponds 11 and 2 in August show a loss of se between the entry into pond 2 and the terminal pond 11 although the increase in $\mathrm{Na}$ shows the water is more concentrated in pond 11 . The $\mathrm{D} / \mathrm{H}$ and ${ }^{18} \mathrm{O} / \mathrm{1}^{16} \mathrm{O}$ values (Table 2 ) show a normal evaporation trend. An analysis of the thenardite $\left(\mathrm{Na}_{2} \mathrm{SO}_{4}\right)$ precipitated from pond 11 showed the salt contains 1.8 parts per million (ppm) Se, dry weight. That is a ratio of $\mathrm{Se} / \mathrm{Na}$ of $3.75 \times 10^{-6}$. The water in the pond where thenardite was found contains $14 \mu \mathrm{g} / \mathrm{L}$ Se and $6,250 \mathrm{mg} / \mathrm{L} \mathrm{Na}$, a ratio of $2.2 X$ $10^{-6}$. Obviously the $S e$ is only partly lost to thenardite; the crystallization of thenardite results in an Increase in the Se/Na in the remaining water and thus is inadequate to account for the Se decrease between pond 2 and 11. Microscopic examination revealed that the thenardite contained small amounts of algae.

The thenardite crust rested upon a mat of the filamentous algae Microspora with strands of the blue-green alga Lyngbya(?)aesturii. The mat also included larger woody debris. Acid oxidative digestion of the mat with a subsequent reduction and analysis of the decanted solution showed the algal mat contains an average of 13 ppm Se (dry weight). Clearly some algae take up Se. This amount of Se may be different from an amount of Se that could be leached from the mat by water (i.e. water-soluble Se), under the conditions obtalned in the pond. Although this experiment is not definitive it does show that organic uptake of the Se is probably much more effective in removing Se than Inorganic processes. The algae being primary producers, are one point of entry of Se into the food chain of higher organisms. 
Crystals were found in both acidified, filtered samples of pond 11 collected in August after return to the laboratory. The precipitate, identified as gypsum clearly was grown from solution after sample collection. A nearly saturated leachate solution of that gypsumproduced a Se value of $<1 \mathrm{ppm}$ (dry weight). Even though this gypsum is an artifact and may differ from natural deposits the results show that gypsum does not tolerate much $\mathrm{SeO}_{4}^{-2}$ substitution for the sulfate $\left(\mathrm{SO}_{4}^{-2}\right)$ in the crystal structure.

The question of cycling of Se through the ponds and/or through the food chain is complicated by the chemistry of Se itself with oxidation states of +6 to -2. Organic selenides $\left(S e^{-2}\right)$ were not looked for. The form of Se in the water $\left(\mathrm{Se}^{+4}\right.$ or $\left.\mathrm{Se}^{+6}\right)$ or whether it is bound to organic material in the water, is not yet fully known. The preliminary data suggest a predominance of selenate.

The results of Se analyses in this study (T. S. Presser) compare closely with those obtained by the U.S.Geological Survey, the Water Resources Division Central Laboratory, Denver, Colorado, (J. Schoen, written commun., Feb. 1984) and results obtained by analysts in the U.S. Fish and Wildlife Service (U.S.F. \&W.S.) Laboratory, Columbia, Missouri, (T. May, oral cormun., Feb. 1984) whether using the same or different methods. For example, as shown in table 3 Kesterson Pond 2 was analyzed by both T. S. Presser (U.S.G.S.) and T. May (U.S.F. \& W.S.) in August, 1983. The U.S.F. \& W.S. samples were considered preliminary. If only the generation of $\mathrm{H}_{2} \mathrm{Se}$ is performed without oxidizing organic matter or reducing the selenate the results are, respectively, 67 and $50 \mu \mathrm{g} / \mathrm{L} \mathrm{Se}$. If the oxidation of the organic matter is omitted but $\mathrm{SeO}_{4}^{-2}$ is reduced to $\mathrm{SeO}_{3}^{-2}$ before reduction to $\mathrm{H}_{2} \mathrm{Se}$ the results are much higher and 
Table 3.--Comparison of results of analyses for Se

Kesterson Pond \#2 (August 3, 1983)

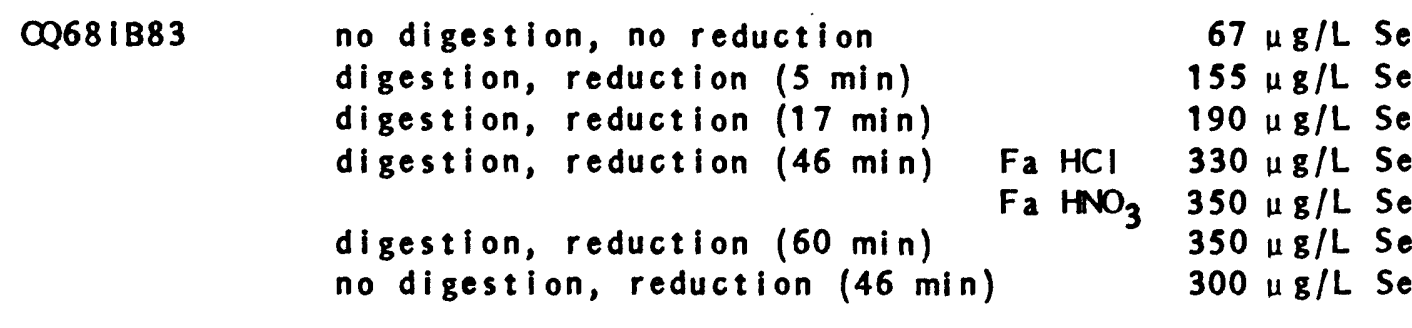

T. May (U.S.F. \& W.S.) (August, 1983)

no digestion, no reduction

$50 \mu \mathrm{g} / \mathrm{L} \mathrm{Se}$

no digestion, reduction

$360 \mu \mathrm{g} / \mathrm{L} \mathrm{Se}$

Inflow from San Luis Drain into Pond \#2

Q119TP83

no digestion, no reduction

digestion, reduction ( $46 \mathrm{~min}$ )

$18 \mu \mathrm{g} / \mathrm{L} \mathrm{Se}$ $280 \mu \mathrm{g} / \mathrm{L} \mathrm{Se}$

\title{
U.S.G.S. Denver Central Lab
}

( ) anuary 24, 1984)

digestion, reduction

$275 \mu \mathrm{g} / \mathrm{L} \mathrm{Se}$

Inflow to San Luis Drain at American Road

(December 2, 1983)

CQ127TP83

no digestion, no reduction

digestion, reduction (46 min) $\mathrm{Fa}-\mathrm{HCl} 1350 \mu \mathrm{g} / \mathrm{L}$ Se

$\mathrm{Fa}-\mathrm{HNO}_{3} \quad 1400 \mu \mathrm{g} / \mathrm{L}$ Se

\section{Standard Reference Water Sample \\ Trace-85}

SRS-T85

no digestion, no reduction

digestion, reduction (46 min)

Reported Mean

\author{
$1.4 \mu \mathrm{g} / \mathrm{L} \mathrm{Se}$ \\ $3.4 \mu \mathrm{g} / \mathrm{L} \mathrm{Se}$ \\ $2.9 \pm 0.5 \mu \mathrm{g} / \mathrm{L} \mathrm{Se}$
}


again the two laboratories agree. The results are:

$$
\begin{array}{lr} 
& \mu g / L \text { Se } \\
\text { U.S.G.S. } & 300 \\
\text { U.S.F. \& W.S. } & 360
\end{array}
$$

Two Independent laboratories and two different methods are thus in close agreement. A sample of the inflow from the San Luis Drain into Kesterson Pond 2 was analyzed both by T. S. Presser, U.S.G.S., Menlo Park, and the U.S.G.S. Central Laboratory, Denver, Colorado. The Central Laboratory used a standard automated method (Fishman and Bradford, 1982). Both oxidation of organic matter and reduction of $\mathrm{SeO}_{4}^{-2}$ to $\mathrm{SeO}_{3}^{-2}$ were done but by different methods. The results are:

$$
\mu \mathrm{g} / \mathrm{L} \text { Se }
$$

$$
\begin{array}{ll}
\text { T. S. Presser } & 280 \\
\text { Central Laboratory } & 275 .
\end{array}
$$

The same sample with neither oxidation of organic matter nor reduction of selenate yielded $18 \mu \mathrm{g} / \mathrm{L}$ Se. An extreme example of the possible effect of Se speciation on analytical results is sample CQ127TP83 of this study. Analysis with neither oxidation of organic matter nor reduction of $\mathrm{SeO}_{4}^{-2}$ to $\mathrm{SeO}_{3}^{-2}$ before $\mathrm{H}_{2}$ Se generation yields but $20 \mu \mathrm{g} / \mathrm{L}$ Se where analyses after both oxidation of organic matter and reduction of $\mathrm{SeO}_{4}^{-2}$ to $\mathrm{SeO}_{3}^{-2}$ gives Se values of $1350 \mu \mathrm{g} / \mathrm{L}$ Se ( $\mathrm{HCl}$ allquot) and $1400 \mu \mathrm{g} / \mathrm{L}$ Se ( $\mathrm{HNO}_{3}$ allquot).

Sample SRS T85 was analyzed by T. S. Presser as a participant in the U.S.G.S Standard Reference Water Sample Program. This program provides standard samples for analytical data quality control in the participating laboratorles. The undigested, unreduced value obtained on this sample was 1.4 $\mu g / L$ Se. The digested, reduced concentration was $3.4 \mu g / L$. The reported mean for 10 laboratories using the hydride procedure and 17 laboratories using a 
flameless atomic absorption procedure was $2.9 \pm 0.5 \mu \mathrm{g} / \mathrm{L}$ Se at the $95 \%$ confidence interval.

\section{SUMMARY AND CONCLUSIONS}

Selenium determinations by three laboratories using three methods yield comparable results for water samples. Two laboratories also performed Se determinations without oxidizing organic matter and without reducing $\mathrm{SeO}_{4}^{-2}$ to $\mathrm{SeO}_{3}^{-2}$ before determining the Se. The results show that a preliminary oxidation of organic matter which converts all Se present to $\mathrm{SeO}_{4}^{-2}$, followed by a reduction step to convert the $\mathrm{SeO}_{4}^{-2}$ to $\mathrm{SeO}_{3}^{-2}$, is needed to yield consistently accurate results for total Se in water samples.

The results of analyses given in this report for Se in water show that all actively flowing agricultural drain waters entering the San Luis Drain that were sampled have at least $140 \mu \mathrm{g} / \mathrm{L}$ Se and as high as $1,400 \mu \mathrm{g} / \mathrm{L}$ Se. The results also show that Se can enter the food chain by uptake by algae.

Based on the various uses of water, several maximum-concentration criteria and standards have been established for Se. Although these criteria and standards do not apply to waters of the San Luis Drain service area, they provide useful perspective about the hazard associated with above-normal concentrations of Se. Further perspective is provided by studies of dietary requirement, average intake, and levels at which toxicity is evidenced. The units used for dosage are parts per billion (ppb), micrograms ( $\mu g$ ) and ki lograms $(\mathrm{kg})$. Se is an essential dietary requirement for many animals; the requirement is estimated to be 40-100 ug Se/kg of food (40-100 ppb) (Schwarz, 1960; Nesheim and Scott, 1961; Oldfield, Schubert and Muth, 1963). No such requirement for humans has been established. The average daily dietary intake by the American population is $200 \mu \mathrm{g}$ Se/day (Morris and Levander, 1970; U.S. Environmental Protection Agency, 1977). Smith and Westfall (1937) reported 
symptoms of chronic toxicity at 10 to $100 \mu \mathrm{g} \mathrm{Se} / \mathrm{kg} / \mathrm{day}$, which for a $70 \mathrm{~kg}$ man would amount to a dally intake of 700 to $7000 \mu \mathrm{g} / \mathrm{day}$. The U.S. Environmental Protection Agency (1977) set the public drinking water maximum contaminant limit at $10 \mu \mathrm{g} / \mathrm{L}$ Se, based on the assumption that $2 \mathrm{~L}$ of water per day would be consumed and that water should provide no more than a $10 \%$ increase in the average daily intake of Se. They further state that the basal $200 \mu g / d a y$ intake plus the $20 \mu \mathrm{g} /$ day from water nresults in a minimum safety factor of 3 , considering the lower end of the range of selenium intakes that have been associated with minor toxic effects in man." The U.S. Environmental Protection Agency (1980) also specifies the concentration of Se in waste that will qualify the waste as "hazardous" under the Resource Conservation and Recovery Act of 1976, provided the source is not exempted. The Se concentration meeting the "characteristic" criteria for hazardous waste is $1000 \mu \mathrm{g} / \mathrm{kg}$ if solid waste or $1000 \mu \mathrm{g} / \mathrm{L}$ in the case of water having a density near 1.0. Based on the preceding considerations, it is apparent that some ground water entering the San Luis Drain contains Se in concentrations exceeding the maximum contaminant level for public water supplies by 140 times and exceeding the lower end of the range of Se intake associated with minor toxic effects in man by 2-4 times, without consideration of dietary intake. Se can exist in multiple oxidation states in water. In the hydride generation technique for Se analysis, different sensitivities are exhibited in the two states $\mathrm{Se}^{+4}$ and $\mathrm{Se}^{+6}$. This supposed disadvantage has potential for use in selective determinations. Determination of se speciation leads in turn to information on oxidation potential, mobility and toxicity of Se in water. 


\section{REFERENCES}

Anderson, M. S., Lakin, H. W., Beeson, K. C., Smith, F. F. and Thacker, Edward, 1961, Selenium in agriculture. Agriculture Handbook No. 200.

U.S. Agricultural Research, 65 p.

Chan, Y. K., Wong, P. T. S. and Goulden, P. D., 1975, Gas chromatographyatomic absorption method for the determination of dimethyl selenide and dimethyl diselenide. Analytical Chemistry, v. 47, pp. 2279-2281.

Cheam, Venghout and Agemian, Hair, 1980, Preservation and stability of inorganic selenium compounds at ppb levels in water samples. Analytica Chimica Acta, v. 113, pp. 237-245.

Cutter, G. A., 1978, Species determination of selenium in natural waters. Analytica Chimica Acta, v. 98, pp. 59-66.

Cutter, G. A., 1982, Selenium in reducing waters. Science, v. 217, pp. 829831.

Cutter, G. A., 1983, Elimination of nitrite interference in the determination of selenium by hydride generation. Analytica Chimica Acta, v. 149, pp. $391-394$.

Goulden, P. D. and Brooksbank, Peter, 1974, Automated atomic absorption determination of arsenic, antimony and selenium in natural waters. Analytical Chemistry, v. 46, pp. 1431-1435.

Morris, V. C. and Levander, O. A., 1970, Selenium content of foods: Journal of Nutrition, v. 100, pp. 1383-1388.

Nakahara, T., 1983, Applications of hydride generations techniques in atomic adsorption, atomic fluorescence and plasma atomic emission spectroscopy. Progress in Analytical Atomic Spectroscopy, v. 6, pp. 163-223.

Nesheim, M. C. and Scott, M. L., 1961, Nutrition effects of selenium compounds in chicks and turkeys: Federal Proceedings 20, pp. 674-678. 
Oldfield, J. E., Schubert, J. R., and Mugh, O. H., 1963, Implications of selenium In large animal nutrition: Journal of Agricultural and Food Chemistry, v. 11, pp. 388-390.

Pierce, F. D. and Brown, H. R., 1977, Comparison of inorganic interferences in atomic absorption spectrometric determination of arsenlc and selenium, Analytical Chemistry, v. 49, pp. 1417-1422.

Presser, T. S. and Barnes, Ivan, 1974, Special techniques for determining chemical properties of geothermal water. U.S. Geological Survey WaterResources investigations 22-74, 11 .

Schwarz, K., 1960, Factor 3, selenium and vitamin E: Nutrition Reviews, $v$. 18, pp. 193-197.

Shendrikar, A. D. and West, P. W., 1975, The rate of loss of selenium from aqueous solution stored in various containers. Analytica Chimica Acta, r. 74, pp. 189-191.

Smith, M. I and Westfall, B. B., 1937, Futher field studies on the selenium problem in relation to public health: Public Health Reports, v. 51, pp. 1496-1505.

U.S. Bureau of Reclamation, 1984, Information on Kesterson Reservoir and waterfowl. U.S. Bureau of Reclamation, Central Valley Project, California, $11 \mathrm{p}$.

U.S. Environmental Protection Agency, 1971, Methods for chemical analysis of water and wastes. Enviornmental Protection Agency, National Environmental Research Center, Analytical Quality Control Laboratory, Cincinnati, Ohio, $312 \mathrm{p}$.

U.S. Environmental Protection Agency, 1977, National interim primary drinking water regulations: Environmental Protection Agency, Office of Water Suppiy, EPA-570/9-76-003, 159 p. 
U.S. Environmental Protection Agency, 1980, Hazardous waste management system: Federal Register, v. 45, no. 98, pp. 33063-33285. U.S. Geological Survey, 1982, A supplement to methods for the determination of inorganlc substances in water and fluvial sediments, M. J. Fishman and W. L. Bradford, eds., U.S. Geological Survey Techniques of Water-Resources Investigations Book 5, Laboratory Analysis, Chapter A1, U.S. Geological Survey Open-File Report 82-272, 16 p. 